\title{
A technique for laboratory sub-sampling of non marine fossil Ostracoda
}

\author{
DAN L. DANIELOPOL \& LIVIA CASALE \\ Limnological Institute. Austrian Academy of Sciences \\ A-5310 Mondsee
}

\begin{abstract}
A two-stage sampling method for large samples of selected species of ostracods is described. The washed sample is sieved through several sieves to ensure the retention and partial separation of the adults and the last instar stages. Each fraction is then sub-sampled in a micropalaeontological sorting tray. The statistical treatment for the estimation of the total number of valves of the selected species is described. Comparative data using the Askö-splitter are also presented. The advantages of the two-stage sampling method in the tray are emphasised.
\end{abstract}

\section{INTRODUCTION}

Many limnetic ostracods are abundant in the prealpine lakes in Central Europe. Their carapaces and valves fossilise well and therefore the palaeolimnologist finds for some abundant species such a very high number of shells that it is difficult to quantitatively estimate their total density. Several solutions have been proposed:

1. The total sample size may be reduced by using a sample splitter, e.g. the Lauer sediment splitter initially devised for sedimentological analysis (see Müller. 1967).

2. Other ostracodologists use semi-quantitative methods and count only a fraction of the original sample and then optically estimate the approximate total number. In such cases the abundances are commonly expressed as arbitrary classes of numbers (see Löffler, 1983). An additional difficulty arises when trying to sample ostracod shells from sediments which are rich in organic detritus. After sieving and drying the sediment residue, it partly aglutinises and it is difficult to separate and/or to extract the ostracod shells which are very thin and fragile as some stick to detritus particles. Problems also arise when one wishes to sub-sample dry sediment residues as they cannot be homogenised and the ostracods are not distributed randomly within the sample. In this latter situation such splitters as Lauer's or that of Kennard \& Smith (described by Rupp, 1986) do not work properly. These difficulties have not been commonly recorded in the published literature because ostracodologists using sediment splitters do not systematically check if the ostracods are randomly distributed in their samples. To overcome the problems arising with the dry and aglutinated sediments, it is possible to extract the ostracods from the samples under water. This method has been used by Löfler (pers. comm. to D.L.D.).

Here is proposed a quantitative method of subsampling in the laboratory for selected species which are abundant. The method also allows an easier separation that is quantitative for the final instars. Therefore, not only an accurate estimation of the total ostracod shells in the sample is obtained but also information on the palaeo-population structure. The method and its statistical treatment is derived mainly from the limnological literature (Edmondson. 1971; Bournaud. 1977; Elliott. 1977; McCauley, 1984). The method is particularly suitable for the estimation of total densities of selected ostracod species of taxocenes from Holocene to Recent lacustrine deposits.

The need to identify qualitatively and quantitatively the larval stages of ostracods has been emphasised recently by Löffler (1986). Whatley (1983a, 1983b) demonstrated for marine ostracods how the reconstruction of the palaeo-population structure in an ostracod sample can be used to better understand the palaeoenvironment and its dynamics. For instance, an ostracod assemblage in which the species are represented by adults and most of the larval stages is indicative of a low energy environment, whereas the opposite, i.e. palaeopopulations represented by shells of only adults and/or late-stage instars, could be interpreted as a thanatocoenosis deposited in a high energy environment.

\section{THE TWO-STAGE SAMPLING METHOD - A DESCRIPTION}

\section{Sample preparation}

The sediment first has to be sieved through coarse and fine sieves (in these experiments larger than 
$600 \mu \mathrm{m}$ and finer than $200 \mu \mathrm{m}$ ). In this way, the larger debris and the very fine silty clay and partly fine sand fractions are eliminated. The sediment residue retained for analysis is checked for the ostracod assemblage and the rare species are directly extracted from the total residue. The residue containing the abundant species selected for sub-sampling is further sieved through one to four sieves in order to separate it into more homogenous fractions. The sieve mesh-sizes should be chosen dependent on the height of the ostracod shells of the adult and the larval stages. It is considered useful to use at least two sieves, one of which allows the retention of the adults and the last 2-3 instars and a finer sieve which retains the small larval instars. Each sieved fraction can be further elutriated by shaking and pouring out the supernatant in order to discard the fine organic detritus and the mineralogenic fine sediment which otherwise obscures the ostracod shells. Note that the elutriation process is not related to specific ostracod species. This is a trial and error operation that depends on specific situations. The sediment residue with ostracods from each sieve has to be spread under water in a micropalaeontological tray. A Fema tray from Rudolf Stratman, Salzgitter-Bad, West Germany, was used. The size of the tray is $45 \mathrm{~cm}^{2}(5 \times 9 \mathrm{~cm})$ divided in 45 equal quadrats (sampling units). The walls are oblique. The material has to be spread over the whole surface of the tray in a thin and homogenous layer using a fine brush. In this way the ostracod shells are spread randomly in the tray. The operation is easily achieved because the sediment and the ostracods are of more or less homogeneous size.

\section{Sub-sampling strategy}

We select a random sub-sample of 15 cells. In order to prevent any bias the $5 \times 9 \mathrm{~cm}$ tray is divided into two (even more) homogenous strata : the 24 peripheral squares and the 21 central squares. To these two strata the 15 squares of the sub-sample are allocated proportionally, e.g. the sub-sample consists of 8 peripheral and 7 central squares. A table of random numbers is used to provide random samples for both strata (see sampling design in Fig. 1). From each of the 15 sub-sampling units the sediment is pipetted out and the ostracods put into small petri dishes. The counting and identification of the ostracod valves is then carried out for each sampling unit. The carapaces were counted as two valves. Because the ostracod material in the sub-sampling units was not abundant and rather homogeneous, the identification of the instars counted could be completed very efficiently. It should be noted here that it is easier for an operator to identify only $2-3$ shell-shape types which morphologically are rather similar, (e.g. Fig. 3) than to be confronted with the whole series of instar shapes displayed by an ostracod species.

\section{Statistical analysis}

The following statistical operations were used: the arithmetic mean and the variance of the sample were computed for each sample. A Chi square test (variance to mean ratio) was used in order to check the agreement with Poisson series (random distribution). For details see Elliott (1977). Deviation from random distribution is especially indicated when the value of the variance is much higher than the arithmetic mean. If no deviation from Poisson series was indicated the point estimate for $N$ was calculated by $\hat{N}=\bar{x} .45=3$.c.

The following terms and symbols have been used: $N\left(N_{s f}\right)$ - unknown number of ostracod shells in the tray respectively sieve fraction $(s f)$. In the next examples, we use the residues of three sieves $(200 \mu \mathrm{m}, 310 \mu \mathrm{m}$ and $500 \mu \mathrm{m}$, hence $\left.N=N_{200}+N_{310}+N_{5(0)}\right)$.

$c\left(c_{s f}\right)$ - total count (respectively count for specific sieve fraction) of the sub-sample, $c=\sum_{i=1}^{15} x_{i}$, hence $c=$ $c_{200}+c_{310}+c_{500}$

$x_{i}$ - number of valves in the $i$-th square (respectively from one sieve fraction) of the sub-sample.

$\bar{x}\left(\bar{x}_{s f}\right)$ - the arithmetic mean, $\bar{x}=c / 15,\left(x_{\mathrm{sf}}=c_{\mathrm{s} f} / 15\right)$. $s^{2}$ - sample variance, $s^{2}=\sum(x-\bar{x})^{2} / n-1$

$\chi^{2}$ test - variance to mean ratio for agreement with a Poisson series, $\chi^{2}=s^{2}(m-1) / \bar{x}$

$n$ - number of sub-sampling units (cells), e.g. in Fema tray $n=15$.

If the distribution was found to be contagious the data were transformed by $\log x$ and the geometric mean $(\hat{x})$ calculated as suggested by Elliott (1977), in our case $\hat{N}=\hat{x} .45$.

In those cases where several sieve fractions were used and where the ostracod distribution in those samples did not indicate a deviation from Poisson series, the counts were summed and the point estimate of the ostracod population of the initial sediment was calculated. This is permissable as a number of independent Poisson random variables is also a Poisson. Note that the sub-sampling units from the different sieve

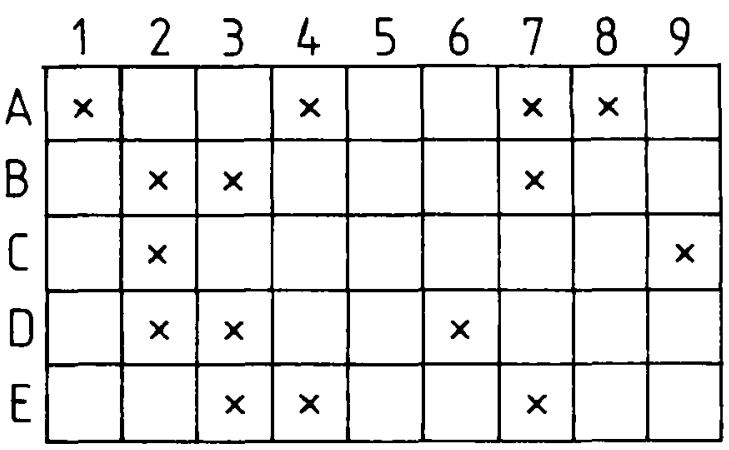

Fig. 1. The Fema micropalaeontological tray and the sampling design used to sub-sample ostracod shells. 
fractions do not have to be summed as the ostracod material is not equivalent in the various fractions. It behaves like different species, i.e. on the larger mesh sieves more adults and last instar stages are retained whereas on the finer mesh size sieves accumulate the younger stages. For random distribution, the lower $\left(N_{L}\right)$ and upper $\left(N_{U}\right) 95 \%$ confidence limits (C.L. 95\%) for $N$ are derived from those for the parameter $m$ (e.g. the expected value) of the Poisson distribution describing the sub-sample. In the proposed subsampling procedure, the confidence limits are expressed by $N_{L}=3 \cdot m_{L}, N_{U}=3 \cdot m_{U}$, where $m_{L}=\frac{1}{2} \chi^{2} 0.025$, $2 c$ and $m_{U}=\frac{1}{2} 0.975,2(c+1)\left(\chi^{2} p, n\right.$ being the $p$-quantile of the $\chi^{2}$ distribution with $n$ degrees of freedom). When $c \leq 300$ one can obtain the tabulated values of $95 \%$ confidence limits from the tables of Crow \& Gardner (1959), for $c>300$ we use the approximations

$$
m_{L} \triangleq c\left(1-\frac{1}{9 c}-1.96 \sqrt{\frac{1}{9 c}}\right)^{3}
$$

and

$$
m_{U^{\prime}} \hat{=}(c+1)\left(1-\frac{1}{9(c+1)}+1.96 \sqrt{\frac{1}{9(c+1)}}\right)^{3}
$$

derived from the approximation for $\chi_{p, n}^{2}$ indicated in Pearson \& Hartley (1966, Vol. 1, p. 137), see also Larsen \& Marx (1986, p. 327).

Note that it is not allowed to sum the confidence limits of the various estimates of the sieve fractions. Therefore. confidence limits should be calculated only once, e.g. for the total estimate of the ostracod material. Other methods to compute confidence limits for random distributions are given in Bournaud (1977), Eliiott (1977). Pielou (1971). Sokal \& Rohlf (1969), and for non-random distributions in Elliott (1977 and Parson et al. (1984). Kimble (1978) uses expression $1.96 \times S . D$. (standard deviation) when calculating confidence limits $95 \%$ for a normal distribution. However, if the assumption of Poisson series are met, it is more appropriate to use the presented construction of confidence limits.

\section{PRACTICAL EXAMPLES}

Here, this method is demonstrated using Recent and sub-fossil ostracods from the lacustrine sediments of Mondsee, a pre-alpine lake in Upper Austria. For the ostracod fauna of this lake and its ecological problems see Löfler (1972) and Danielopol et al. (1985). The most common ostracod assemblage in Mondsee is formed by Candona neglecta Sars, $C$. candida Baird, Fabaeformiscandona caudata Kaufm., $F$. protzi Hartw., Cypria lacustris Sars, Limnocythere sanctipatricii Br. \& Rob. and Cytherissa lacustris Sars. In the following example, the ostracod material comes from about $50 \mathrm{~cm}^{3}$ of wet sediment collected from the central part of the lake (the site MO-7) at $12 \mathrm{~m}$ depth using a Kajak corer (for location see Danielopol et al., 1985).

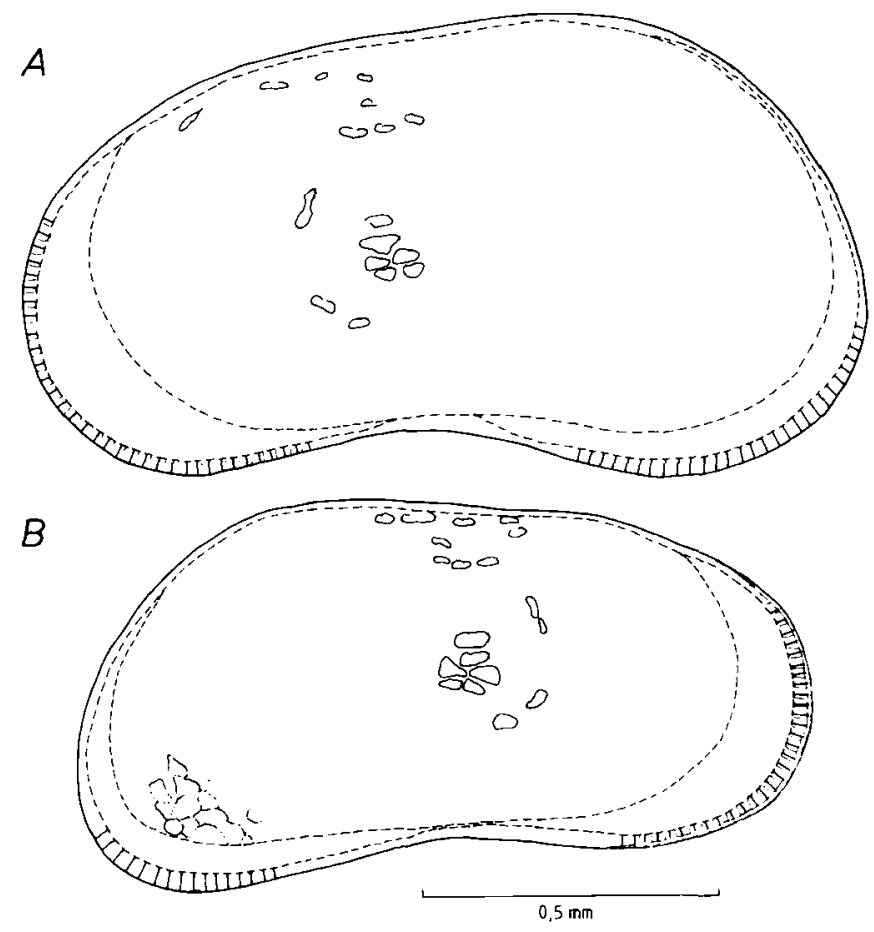

Fig. 2. Candona neglecta Sars. Valves, adult external view: $A$, male left valve; $B$, female, right valve.

C. neglecta and $C$. lacustris are the most abundant species that it was decided to sub-sample. A combination of three sieves was chosen which sorted the ostracod material into more homogeneous size classes, i.e. $500 \mu \mathrm{m}, 310 \mu \mathrm{m}$ and $200 \mu \mathrm{m}$ sieves. The $500 \mu \mathrm{m}$ sieve was chosen in order to retain the adults of both species. They have a shell height of more than $600 \mu \mathrm{m}$ (Fig. 2A, B). The last two instars (7th and 8 th) have shell heights of more than $350 \mu \mathrm{m}$, which is why a sieve with a mesh size of $310 \mu \mathrm{m}$ was chosen. For the retention of the 6th and the 5th instar sizes (Fig. 3), the $200 \mu \mathrm{m}$ mesh sieve was selected. Note that the $100 \mu \mathrm{m}$ and $63 \mu \mathrm{m}$ sieves were not used as these mainly retained the early instar stages ( 2 nd -4 th) which cannot be identified to species level for most of the taxa mentioned above. The residue from these sieves was then spread on a Fema tray as described above. The ostracods and sediment were extracted from 15 randomly chosen cells (Fig. 1). Tables 1 and 2 show the results. For $C$. neglecta in all the three sieve residues the valves were randomly distributed (Table 1). The point estimate for each fraction was calculated further. In order to see how close the estimate lies to the true value, all the individuals of $C$. neglecta and $C$. lacustris were counted. In the case of the latter (Table 2), it has 


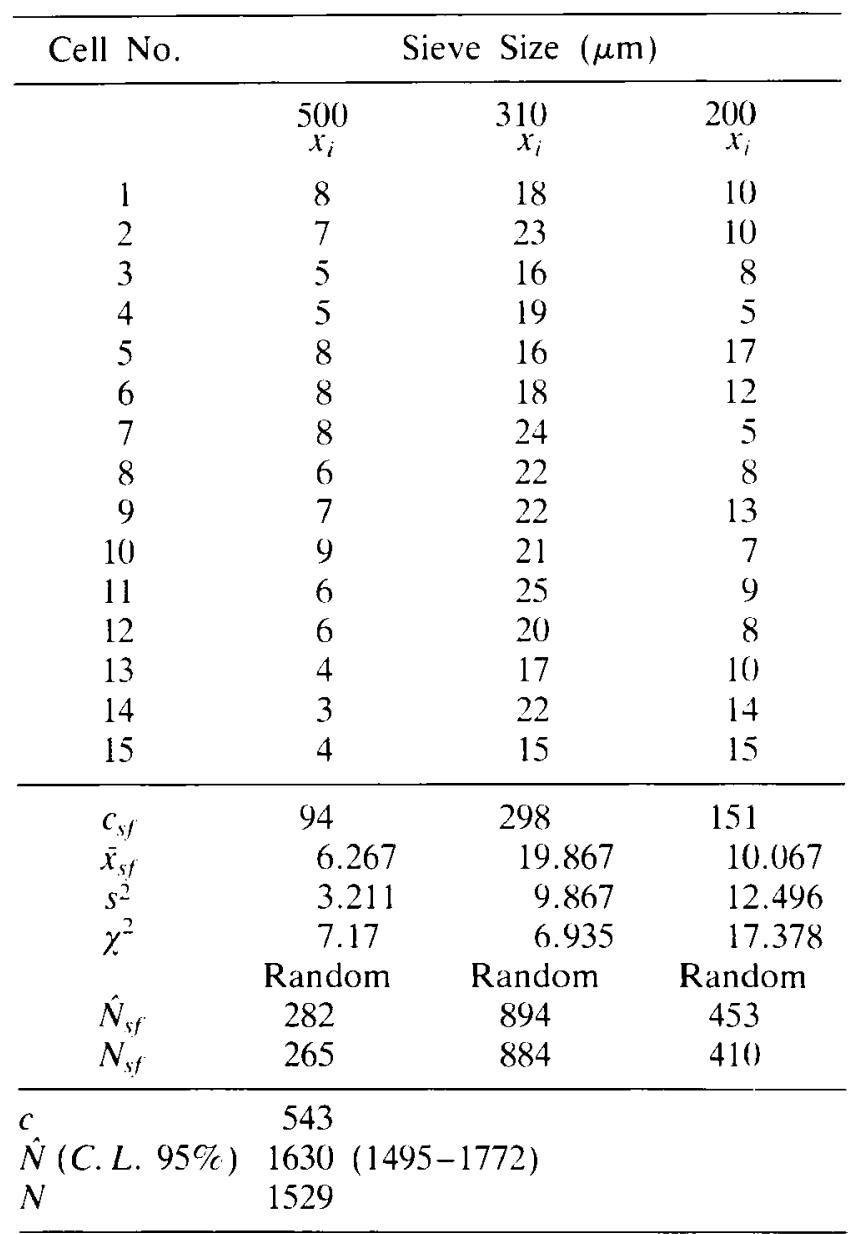

Table 1. Sub-sampling Candona neglecta Sars with a Fema Tray.

to be noted that on the $500 \mu \mathrm{m}$ sieve only few specimens were retained and therefore it was not necessary to sub-sample. The material from the $200 \mu \mathrm{m}$ sieve did not spread randomly. A contagious distribution was assumed and therefore the counts were transformed to $\log x$ and the geometric mean was calculated. The ostracod estimate of the $2010 \mu \mathrm{m}$ fraction was derived from this.

A $95 \%$ confidence limit of the estimate was calculated only in the case of the total count of $C$. neglecta (Table 1) and in the case of the $310 \mu \mathrm{m}$ fraction for $C$. lacustris (Table 2). From Tables 1 and 2 it can be seen that the estimates lie close to the true values. Considering $C$. lacustris from the $200 \mu \mathrm{m}$ fraction (Table 2) it can be seen that the estimate derived from the arithmetic mean would considerably overestimate the true value.

Fig. 4 shows the proportion of different postembryonic stages retained on the three sieves for $C$. neglecta and $C$. lacustris. It can be seen that on the $500 \mu \mathrm{m}$ sieve, about $90 \%$ of adults from this ostracod fraction are retained. On the other hand. the $200 \mu \mathrm{m}$ sieve retains mainly the valves belonging to the 6 th and
5 th instars. The intermediate sieve contains a mixture of adults and the last three instars. For $C$. neglecta, this is due to the fact that some small valves of the 6th stage do not pass through the sieve while the older stages pass through because they have been partly damaged. Because of the good morphological descriptions of the post embryonal stages for these species, it was possible to identify the partly damaged material. In other experiments done by one of us (L.C.). in which a supplementary sieve $(420 \mu \mathrm{m})$ was used, a better separation of the $C$. neglecta stages was achieved.

\section{COMPARATIVE DATA}

Some micropalaeontologists will still remain sceptical of the advantages of this sub-sampling method. It will be argued that the classic method of dividing the sediment into large sampling units (e.g. in several trays) and the further extraction of ostracods from the whole sampling unit (i.e. from the whole tray) would give better estimates. It will also be asked if the

\begin{tabular}{|c|c|c|c|}
\hline \multirow[t]{3}{*}{ Cell No. } & \multicolumn{3}{|c|}{ Sieve Size $(\mu \mathrm{m})$} \\
\hline & 500 & 310 & 200 \\
\hline & & $x_{i}$ & $x_{i}$ \\
\hline 1 & 9 & 5 & 6 \\
\hline 2 & & 7 & 2 \\
\hline 3 & & 11 & 4 \\
\hline 4 & & 3 & 5 \\
\hline 5 & & 9 & 4 \\
\hline 6 & & 7 & 10 \\
\hline 7 & & 1 & 5 \\
\hline 8 & & 6 & 13 \\
\hline 9 & & 8 & 12 \\
\hline 10 & & 7 & 1 \\
\hline 11 & & 4 & 7 \\
\hline 12 & & 4 & 8 \\
\hline 13 & & 6 & 4 \\
\hline 14 & & 2 & 3 \\
\hline 15 & & 6 & 5 \\
\hline$c_{y,}$ & & 86 & 89 \\
\hline $\bar{x}_{s y}^{\prime \prime}$ & & 5.733 & 5.933 \\
\hline$s^{2}$ & & 7.065 & 12.208 \\
\hline$\chi^{2}$ & & 17.253 & 28.807 \\
\hline & & Random & Contagious \\
\hline$\hat{N}_{s j}$ & & $258^{(1)}$ & $267^{(1)}$ \\
\hline & & & $219^{(2)}$ \\
\hline C.L. $95 \%$ & & $205-314$ & \\
\hline$N$ & & 229 & 157 \\
\hline
\end{tabular}

Table 2. Sub-sampling Cytherissa lacustris Sars with a Fema Tray. 

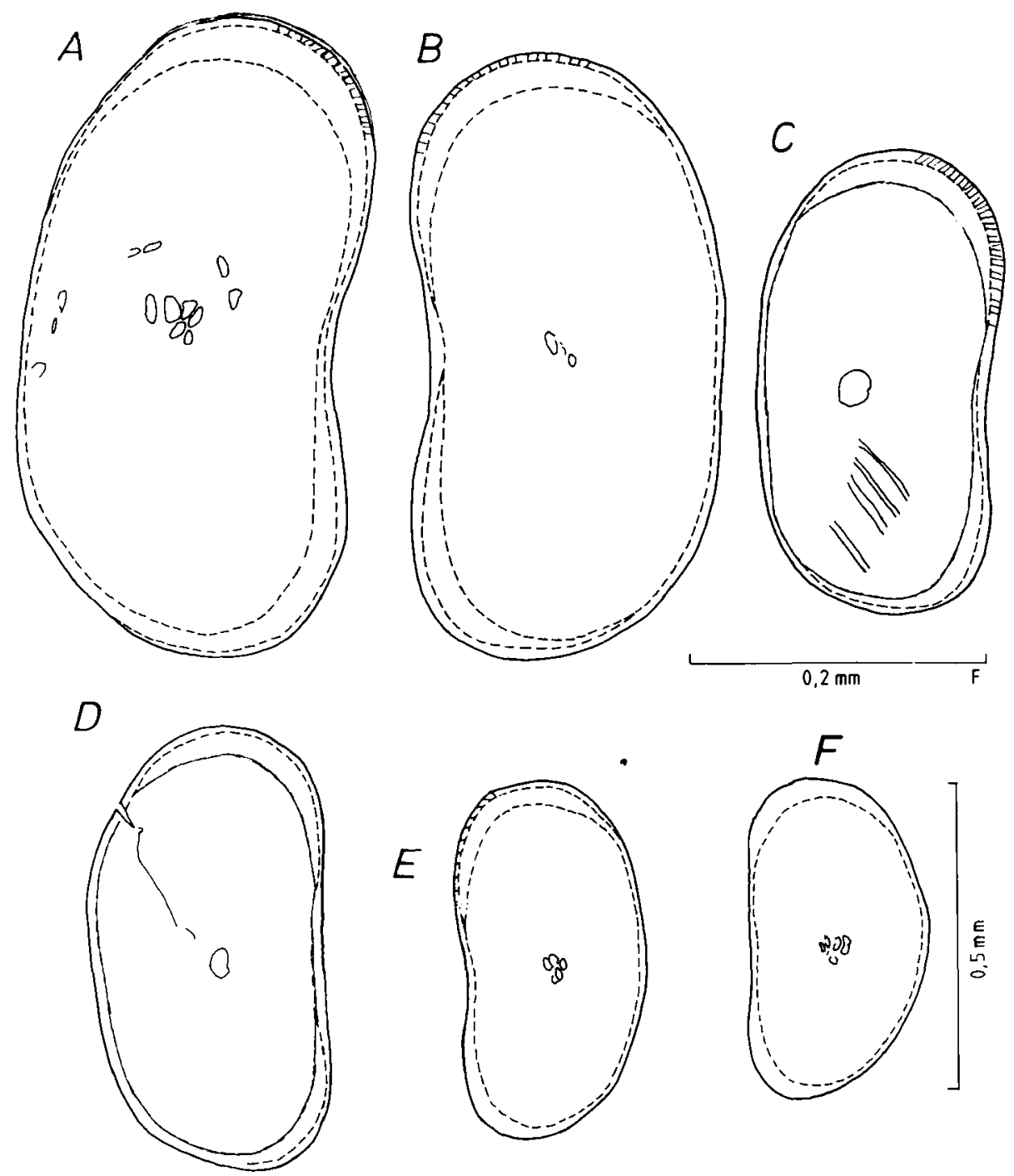

Fig. 3. Candona neglecta Sars. Valves, juveniles: A, B, E-F, external view; C, D, internal view. A, B, 8th instar (A, male, B, female); C, D, 7th instar (C, male, D, female); $\mathrm{E}$, 6th instar; $\mathrm{F}$, 5th instar.

precision and the efficiency of the method proposed here is better than those obtained when sub-sampling with splitters. The basic problem with the type of sediment for which the two-stage method is proposed is that it cannot be successfully homogenised and further divided into equivalent parts, either under dry conditions (as mentioned in the introduction) or under water. In this latter case, by shaking the sediment and water and pouring in various trays successively, an elutriation process is achieved, i.e. the first tray has the lighter sediment fraction and the coarse material passes into the next trays. An alternative solution could be to use the Askö-splitter for dividing the ostracod shell material (Elmgren, 1973) This sample divider has been successfully used for marine and limnetic meïoand macrofauna including living Ostracoda (Elmgren, 1973, Danielopol, 1983, Gage, 1982). Fig. 4 shows the
Askö-splitter used for these experiments. For a description of the operation of the Askö-splitter see Elmgren (1973). The material can be divided into eight parts. For sub-sampling, only three cells chosen with a random number table were used (i.e. the cells numbered 7,4 and 3). The ostracod material used was the $500 \mu \mathrm{m}$ and $310 \mu \mathrm{m}$ sediment residues from the experiment presented in Tables 1 and 2. Each cell unit of the Askö-splitter was separately collected on a $200 \mu \mathrm{m}$ sieve and totally counted in a Fema tray. To check for randomness of the ostracod distribution in this experiment, all the eight cells were examined. Table 3 gives the details for $C$. neglecta and $C$. lacustris. The total number of ostracod shells in the eight cells counted represented the true value. The ostracods from the central fraction (the "o" cell) were divided into eight units and added to the counts of the eight cells (see 


\begin{tabular}{ccc}
\hline Cell No. & $\begin{array}{c}\text { Candona } \\
\text { neglecta }\end{array}$ & $\begin{array}{c}\text { Cytherissa } \\
\text { iacustris }\end{array}$ \\
\hline 0 & 23 & 5 \\
1 & 109 & 21 \\
2 & 106 & 37 \\
3 & 102 & 29 \\
4 & 165 & 30 \\
5 & 103 & 26 \\
6 & 114 & 26 \\
7 & 114 & 32 \\
8 & 105 & 20 \\
$\sum z^{(1)}$ & 941 & 226 \\
$\hat{x}^{(2)}$ & 114.75 & 27.625 \\
$s^{2}$ & 433.056 & 31.697 \\
$\gamma^{2}$ & 26.417 & 8.032 \\
$c^{(3)}$ & Contagious & Random \\
$\hat{N}^{(4)}$ & 390 & 94 \\
\hline & $1040)^{(5)}$ & $251^{(5)}$ \\
\hline
\end{tabular}

(1) $\sum x=x_{0}+x_{1}+\cdots+x_{8}$

(2) $\bar{x}=\frac{x_{11}+\left(x_{1}+x_{2} \cdots+x_{x}\right)}{8}$

see text

(3) $c=x_{3}+x_{4}+x_{7}$

(4) $N$ in splitter for $c$

(5) $\hat{N}$ in tray

C. neglecta -1177

C. lacustris -267

Table 3. Sub-sampling Candona Sars and Cytherissa lacustris Sars with the Askö-splitter (ostracod material from the $500 \mu \mathrm{m}$ and $310 \mu \mathrm{m}$ fractions of Tables 1 and 2).

Elmgren, 1983). It can be seen that when the ostracods from all the cells were counted, the distribution of $C$. neglecta was found to be contagious whereas those of C. lacustris followed a Poisson series. It is difficult to check for the type of distribution of the ostracod shells in the splitter from a reduced number (in this case, three) of sampling units. Increasing the counts to include more cells would reduce the gain of time during the sample count which is the main point of any sub-sampling method. If the point estimates obtained are now compared, i.e. the Fema tray (by adding the $500 \mu \mathrm{m}$ and $310 \mu \mathrm{m}$ fractions), with those of the Askö-splitter, a close agreement is found (Tables 1-3. To increase the precision of the Askö-splitter, an apparatus could be constructed with a higher number of cells. But the operation of removal of the ostracod shells from the splitter always implies supplementary washing and sieving and, subsequently, a potential loss of material. This is obvious when the true value counted on the tray is compared (Tables 1 and 2) with those found in the splitter (Table 3). About 20() valves of $C$. neglecta and 20 valves of $C$. lacustris were lost by the manipulation of the material during the splitter operation. Some valves simply remained attached to the walls of the splitter or to the sieves. Nevertheless, the point estimate for $C$. neglecta with a contagious distribution in the splitter lay close to those of true value in the tray (1040 against 1149 counts). This is fortuitous for if other random numbers for the cells in the splitter were generated, the estimate for $C$. neglecta would look different and this would be difficult to discover without counting all the material.

Another difficulty which occurs when counting large sampling units (in this special case all the $C$. lacustris shells from a Fema tray without subdividing the residue into small units), is that due to operator fatigue, some of the valves are overlooked. One can see here that the precision of the sampling is not only a problem of statistics but also one where the operator and the apparatus used play major roles. This problem has been investigated in a limnological context by Lapchin \& Ingouf-Le Thiec (1977).

In another experiment, the time required for subsampling an ostracod species in the Fema tray and in the Askö-splitter were compared. A sediment residue retained by a $310 \mu \mathrm{m}$ sieve and containing a high number of Cytherissa lacustris shells was used. Table 4 shows the results for the Fema tray. The time required to process the sample and to calculate the ostracod estimate was similar for both methods, i.e. 110 minutes. The distribution of $C$. lacustris in the Askösplitter was contagious and this only became apparent by counting the whole sample which significantly extended the time required to process the sample.

Another question might be how easily it is to achieve a random distribution of the ostracod material in the tray with a fine brush. The data presented here in Tables 1-4 suggest that this is feasible. This problem was checked by one of us (L.C.) in another experiment. by replicating three times the sub-sampling operation using $C$. neglecta valves and the fractions of three sieves $(500 \mu \mathrm{m}, 310 \mu \mathrm{m}$ and $200 \mu \mathrm{m}$ mesh size). In all the trials, random distributions of the $C$. neglecta material were found and for a true value of 1308 valves, the point estimate had been overestimated by between 2.3 and $16.4 \%$.

\section{FINAL REMARKS - THE ADVANTAGES OF THE TWO-STAGE SAMPLING METHOD}

Assuming that the method is intended for Holocene or Recent sediments rich in organic detritus and for ostracods with light shells which cannot be sub-sampled properly when dried, the new method proposed offers the following advantages:

1. It is possible to actively distribute the ostracods and the sediment in order to obtain a random distribution. Using the Askö-splitter this is a passive process and 
cannot be visually controlled by the operator.

2. By dividing the sediment between several sieves a more homogeneous composition of the ostracods is obtained and it is easier to extract and identify larval stages with closely related morphologies.

3. Counting in many small units allows a better precision of the estimate (see discussion also in Elliott. 1977) than in the case of the Askö-splitter method. Meaningful confidence limits for the estimate may be calculated with the tray method whereas with the Askö-splitter, this is more problematic because of the reduced number of sampling units commonly investigated.

4. Operator fatigue during the identification of the ostracod instars in small sample units extracted from the micropalaeontological tray is reduced compared with examining ostracods in large sampling units.

5. Finally, there are enough possibilities to adapt the two-stage sampling method to specific needs of an investigation and it should be remembered: "In any investigation some thought and experimentation should be given to the most efficient way . . . (of working)". (See Edmondson, 1971, p. 133).

We recommend the two-stage sampling method in the micropalaeontological tray to those ostracodologists interested in gaining as much palaeoecological information as possible from their samples.

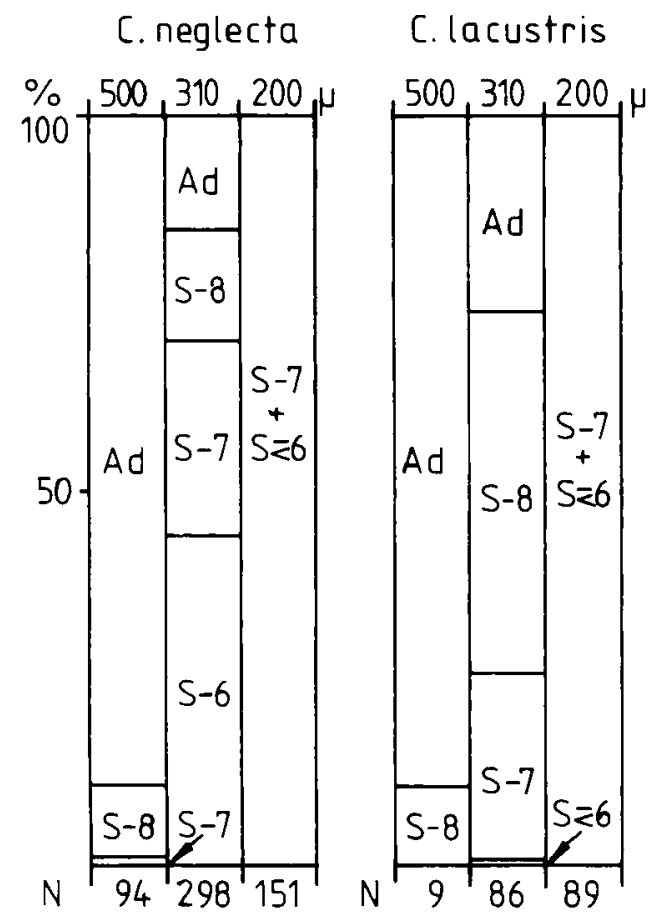

Fig. 4. Percentual distribution of adults and larval stages for Candona neglecta and Cytherissa lacustris in the three sieve fractions $(500 \mu \mathrm{m} .310 \mu \mathrm{m}$. $200 \mu \mathrm{m})$.

\section{ACKNOWLEDGEMENTS}

Prof. H. Löffler (Univ. Vienna) stimulated, through his research interest. the idea of this paper. We are much indebted to various micropalaeontologists who read a first draft of this paper and commented on the sampling techniques used in their own ostracod re-
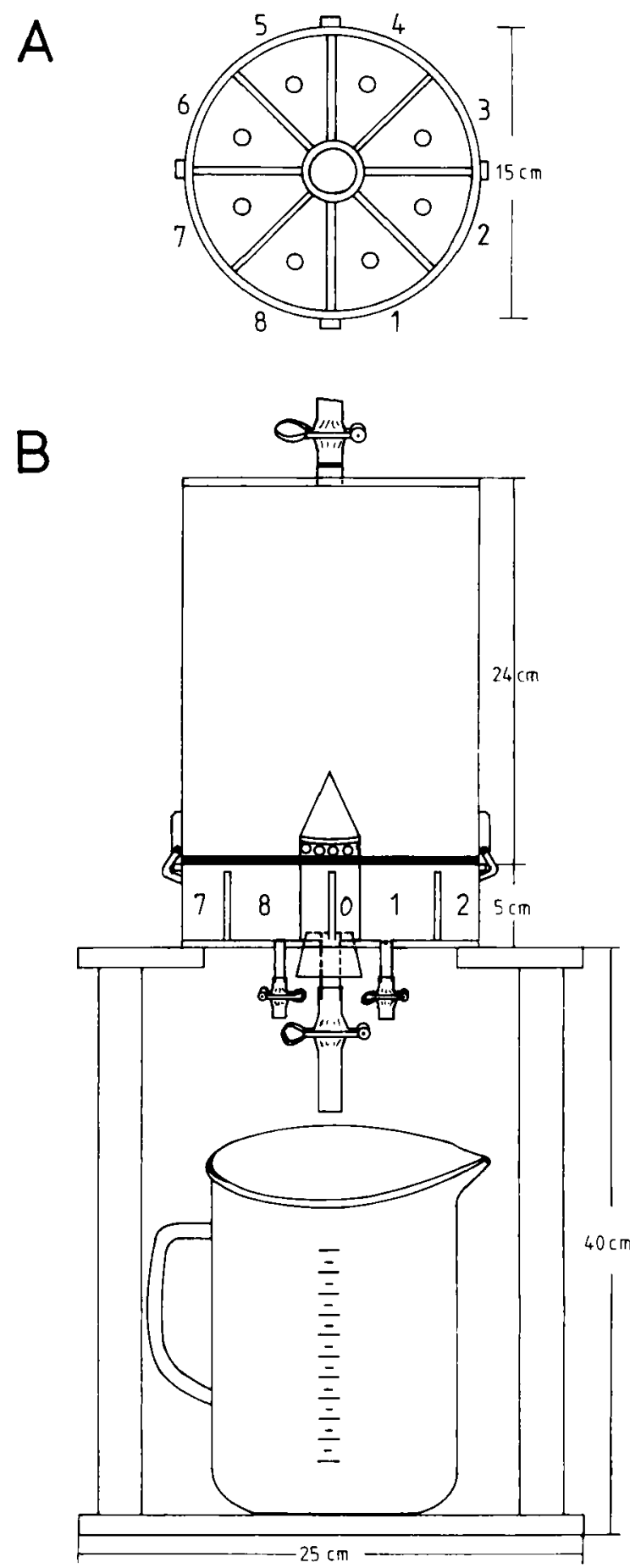

Fig. 5. The Askö-splitter: A the bottom sampling unit; B. general view. 


\begin{tabular}{|c|c|}
\hline Cell No. & $x_{i}$ \\
\hline 1 & 15 \\
\hline 2 & 11 \\
\hline 3 & 9 \\
\hline 4 & 7 \\
\hline 5 & 9 \\
\hline 6 & 13 \\
\hline 7 & 21 \\
\hline 8 & 17 \\
\hline 9 & 14 \\
\hline 10 & 13 \\
\hline 11 & 13 \\
\hline 12 & 18 \\
\hline 13 & 11 \\
\hline 14 & 12 \\
\hline 15 & 12 \\
\hline$c$ & 195 \\
\hline $\bar{x}$ & 13 \\
\hline$s^{2}$ & 13.432 \\
\hline$\chi^{2}$ & 14.465 \\
\hline & Random \\
\hline$\hat{N}$ & 585 \\
\hline C.L. $95 \%$ & $508-669$ \\
\hline$N$ & 521 \\
\hline
\end{tabular}

Table 4. Sub-sampling Cytherissa lacustris Sars with the Fema Tray (ostracod material retained on a $310 \mu \mathrm{m}$ mesh sieve).

search. They are: Drs. R. Whatley (Univ. Coll. Wales, Aberystwyth), N. Pugliese (Univ. Trieste), A. Sokac (Univ. Zagreb), K. Wouters (Royal Museum of Nat. Hist., Bruxelles), U. Grafenstein (T. Univ. Munich), P. Carbonel (Univ. Bordeaux), J.-P. Colin (Esso, Begles), H. J. Oertli (Elf-Aquitaine, Pau), T, HuberMahdi (Univ. Vienna), M. Handl (Univ. Salzburg). For advice in the statistical treatment and sub-sampling design, we acknowledge Drs. J. M. Elliott (FB Assoc., Windermere), F. Österreicher (Univ. Salzburg, Dept. of Mathematics) and an anonymous reviewer. Drs. Whatley, J. M. Elliott and T. Andrew (Univ. Ulster) improved the English style of various drafts of this paper. I. Gradl (Mondsee) typed the manuscript.

The work was partly funded by the "Fonds zur Förderung der wissenschaftlichen Forschung" (Vienna), Project P5614 attributed to the senior author.

\section{Manuscript received December 1986 \\ Revised manuscript accepted June 1987}

\section{REFERENCES}

Bournaud, M. 1977. Quelques méthodes de traitement des données en ecologie. Lecture notes Univ. Lyon 1. Biologie animale et Zoologie Lyon 1, Depart. Biologie animale et zoologie Lyon. $97 \mathrm{pp}$.

Crow, E. L. \& Gardner, R. S. 1959. Tables of confidence limits for the expectation of a Poisson variable. Biometrika. Cambridge, 46, 441-453.

Danielopol, D. L., Geiger, W., Tölderer-Farmer, M., Orellana, C. P. \& Terrat, M.-N. 1985. The Ostracoda of Mondsee: spatial and temporal changes during the last fifty years. In Danielopol, D., Schmidt. R. \& Schultze, E. (Eds.). Contributions to the paleolimnology of the Trumer Lakes (Salzburg) and the lakes Mondsee. Attersee and Traunsee (Upper Austria). Limnol. Inst. ÖAW, Mondsee, 99-121.

Edmondson, W. T. 1971. Methods for processing samples and developing data. In Edmondson. W. T. \& Winberg. G. G. (Eds.), A manual on methods for the assessment of secondary productivity in fresh waters, 127-169. Blackwell Scient. Publ., Oxford.

Elmgren, R. 1973. Methods of sampling sublittoral soft bottom fauna. Oikos Supl., Copenhagen, 15, 112-120.

Elliott, J. M. 1977. Some methods for the statistical analysis of samples of benthic invertebrates Freshwater Biol. Assoc. Sci. Publ. 25, $106 \mathrm{pp}$, Windermere.

Gage, J. D. 1982. An aerated sedimentation column for subsampling large benthic samples from deep-sea sediments. Deep-Sea Res., 29 (5A), 627-630.

Kimble, G. R. 1978. How to use (and misuse) stattstics. Prentice-Hall Inc. Englewood Cliffs, N-J. 290 pp.

Lapchin, L. \& Ingoufe-Le Thiec 1977. Le dépouillement des échantillons d'invertebres benthiques: étude comparée de différentes méthodes de tri. Ann. hydrobiol. . 8, 231-245.

Larsen, R. J. \& Marx, M. L. 1986. An introduction to mathematical statistics and its applications. Prentice-Hall Englewood Cliffs, N-J. 630 pp.

Löffler. H. 1972. The distribution of subfossil ostracods and diatoms in pre-alpine lakes. Verh. int. Verein. theor. angew. Limnol., 18, 1039-1050.

Löfler, H. 1983. Changes of the benthic fauna of the profundal zone of Traunsee (Austria) due to salt mining activities. Hydrobiologia, The Hague, 103, 135-139.

Löffler, H. 1986. Ostracod analysis. In Berglund, B. E. (Ed.), Handbook of Holocene palaeoecology and palaeohydrology, 693-702, J. Wiley \& Sons, Chichester.

McCauley, E. 1984. The estimation of the abundance and biomass of zooplankton in samples. In Downing, J. A. \& Rigler, F. H. (Eds.), A manual on methods for the assessment of secondary productivity in fresh waters (2nd ed.), 228-281. Blackwell Scient. Publ. Oxford.

Müller, G. 1967. Methods in sedimentary petrology. Schweizerbart'sche Verlag., 283 pp., Stuttgart.

Parson, T. R., Maita, Y., Lalli, C. M. 1984. A manual of chemical and biological methods for seawater analysis. Pergamon Press, Oxford, $173 \mathrm{pp}$.

Pielou, E. G. 1974. Population and community ecology. Principles and methods. Gordon \& Beach. Sci. Publ. New York, 424 pp. (3rd printing 1978).

Pearson, E. S. \& Hartley, H. O. 1966. Biometrika. Tables for Statisticians (3rd ed.). Cambridge.

Sokal, R. R. \& Rohlf, F. J. 1969. Introduction to biostatistics. W. H. Freeman \& Co. San Francisco, 368 pp. (reprinted 1973).

Whatley, R. 1983a. Some simple procedures for enhancing the use of Ostracoda in palaeoenvironmental analysis. NPD-Bull., 2, 129-146.

Whatley, R. 1983b. The application of Ostracoda to palaeoenvironmental analysis. In Maddocks, R. (Ed.), Applications of Ostracoda to economic and scientific problems. Univ. Houston, Houston, 51-77. 